\title{
CAPITAL FLOWS AND FINANCIAL STABILITY IN EMERGING ECONOMIES
}

Christopher F Baum, Madhavi Pundit, and Arief Ramayandi

NO. 522

October 2017
ADB ECONOMICS WORKING PAPER SERIES 
ADB Economics Working Paper Series

\section{Capital Flows and Financial Stability in Emerging Economies}

Christopher F Baum, Madhavi Pundit, and Arief Ramayandi

No. 522 | October 2017
Christopher F Baum (baum@bc.edu) is a professor of Economics, Boston College and Research Fellow, DIW Berlin. Madhavi Pundit (mpundit@adb.org) is economist and Arief Ramayandi (aramayandi@adb.org) is senior economist at the Economic Research and Regional Cooperation Department, Asian Development Bank. 
(C) 2017 Asian Development Bank

6 ADB Avenue, Mandaluyong City, 1550 Metro Manila, Philippines

Tel +63 2632 4444; Fax +63 26362444

www.adb.org

Some rights reserved. Published in 2017.

ISSN 2313-6537 (Print), 2313-6545 (e-ISSN)

Publication Stock No. WPS179090-2

DOI: http://dx.doi.org/10.22617/WPS179090-2

The views expressed in this publication are those of the authors and do not necessarily reflect the views and policies of the Asian Development Bank (ADB) or its Board of Governors or the governments they represent.

ADB does not guarantee the accuracy of the data included in this publication and accepts no responsibility for any consequence of their use. The mention of specific companies or products of manufacturers does not imply that they are endorsed or recommended by ADB in preference to others of a similar nature that are not mentioned.

By making any designation of or reference to a particular territory or geographic area, or by using the term "country" in this document, $A D B$ does not intend to make any judgments as to the legal or other status of any territory or area.

This work is available under the Creative Commons Attribution 3.0 IGO license (CC BY 3.0 IGO)

https://creativecommons.org/licenses/by/3.0/igo/. By using the content of this publication, you agree to be bound by the terms of this license. For attribution, translations, adaptations, and permissions, please read the provisions and terms of use at https://www.adb.org/terms-use\#openaccess

This CC license does not apply to non-ADB copyright materials in this publication. If the material is attributed to another source, please contact the copyright owner or publisher of that source for permission to reproduce it. $\mathrm{ADB}$ cannot be held liable for any claims that arise as a result of your use of the material.

Please contact pubsmarketing@adb.org if you have questions or comments with respect to content, or if you wish to obtain copyright permission for your intended use that does not fall within these terms, or for permission to use the ADB logo.

Notes:

1. In this publication, "\$" refers to US dollars.

2. Corrigenda to ADB publications may be found at http://www.adb.org/publications/corrigenda 


\section{CONTENTS}

TABLES

ABSTRACT V v v v v

$\begin{array}{ll}\text { I. INTRODUCTION } & 1\end{array}$

II. DATA AND EMPIRICAL METHODOLOGY 2

A. Data 3

B. Estimation Strategy 4

III. EMPIRICAL FINDINGS

A. Summary of Findings for the Levels of Financial Indicators
versus Levels of Capital Flows

B. $\quad$ A Robustness Check with Annual Data 7

C. Summary of Findings for the Volatility of Financial Indicators
versus the Level of Capital Flows

IV. UNTANGLING THE MIXED EFFECTS

A. Financial Aggregates 10

B. Macroeconomic Variables 11

V. CONCLUDING REMARKS

REFERENCES 


\section{TABLES}

1 Levels of Financial Stability Proxies versus Levels of Capital Flows:

Percentage of Significant Coefficients

2 Levels of Financial Stability Proxies versus Levels of Capital Flows: Significant Positive Coefficients

3 Levels of Financial Stability Proxies versus Levels of Capital Flows:

Significant Negative Coefficients

4 Levels of Financial Stability Proxies versus Levels of Capital Flows:

Net Significant Coefficients

5 Levels of Capital Flows: Percentage of Significant Coefficients

6 Levels of Capital Flows: Significant Positive Coefficients

7 Levels of Capital Flows: Significant Negative Coefficients

8 Levels of Capital Flows: Net Significant Coefficients

9 Volatility of Financial Stability Proxies versus Levels of Capital Flows:

Percentage of Significant Coefficients

10 Volatility of Financial Stability Proxies versus Levels of Capital Flows:

Significant Positive Coefficients

11 Volatility of Financial Stability Proxies versus Levels of Capital Flows:

Significant Negative Coefficients

12 Volatility of Financial Stability Proxies versus Levels of Capital Flows:

Net Significant Coefficients

13 Relation between Financial Aggregates and Estimated Coefficients between Flows and All Financial Indicators

14 Relation between Macroeconomic Aggregates and Estimated Coefficients

between Flows and Financial Indicators 


\begin{abstract}
There is mixed evidence for the impact of international capital flows on financial sector's stability. This paper investigates the relationship between components of gross capital flows and various financial stability indicators for 16 emerging and newly industrialized economies. Departing from panel data methods, for each financial stability proxy, we employ systems of seemingly unrelated regression estimators to allow variation in the estimated relationship across countries, while permitting crossequation restrictions to be imposed within a country. The findings suggest that, after controlling for macroeconomic factors, there are significant effects of different gross capital flow measures on the financial stability proxies. However, the effects are not homogeneous across our sample economies and across flows. Country-specific financial and macroeconomic characteristics help to explain some of these differences.
\end{abstract}

Keywords: emerging economies, financial stability, international capital flows

JEL codes: E44, F41 


\section{INTRODUCTION}

Capital flows are thought of as a mixed blessing for developing and emerging economies. While they bring in much-needed foreign capital to supplement domestic finances to support growth and improve resilience, they also expose the economic and financial systems to external shocks (Kim and Singal 2000). Whether on balance the vulnerability of an economy increases or decreases with capital movements remains an open empirical question despite a large body of literature (Kose et al. 2009). For example, the relationship between capital flows and macroeconomic volatility in emerging economies is ambiguous and may depend on the nature of flows (Hegerty 2011), on the level of financial development of the economy (Kose, Prasad, and Terrones 2003), or country characteristics (Milesi-Ferretti and Tille 2011; and Ahmed and Suardi 2009).

In this paper, we assess the relationship between capital flows and financial stability in emerging economies. By using disaggregated levels of gross capital flows for 16 emerging and newly industrialized economies we investigate their relevance for explaining volatility in multiple financial sector indicators, used as proxies for measuring financial stability.

The effect of capital flows on financial stability in emerging markets has gained interest for its potential consequences for macroeconomic stability as recent crises have revealed (Erturk 2005; and Kaminsky and Reinhart 1999). Some believe that financial liberalization in developing economies (domestic deregulation and opening of the capital account) is followed by instability and crises for reasons such as underdeveloped institutions and banking systems, and an increase in competition and risk-taking as the process of liberalization evolves (Corsetti, Pesenti, and Roubini 1999; and Daniel and Jones 2007). Others believe that financial openness fosters stronger and more stable financial systems owing to greater access to capital (Kaminsky 2005; and Kaminsky and Schmukler 2008). Again the evidence is inconclusive.

The literature on financial flows recognizes that unbundling the composite capital account adds richness to the analysis as flows are heterogeneous in nature and possibly in their impact. For example, portfolio debt and equity inflows are considered volatile because they are driven by speculative considerations. On the other hand, foreign direct investment (FDI) inflows are considered to be stability inducing, compared with portfolio and other investment flows, because they are less prone to fluctuations and reversals in the short term. Conventionally, FDI involves investment in fixed assets in an economy and is driven by long-term considerations. Hence, these flows are associated with continuity over a period of time. Accordingly, studies find evidence that FDI is the least volatile among financial flows in general and, particularly, during episodes of sudden stops in crises in developing and emerging economies (Wei 2001, Albuquerque 2003, Levchenko and Mauro 2007, and Sula and Willett 2009).

But other studies show that FDI flows are as volatile as other flows, and may not always be stabilizing (Claessens, Dooley, and Warner 1995; Bird and Rajan 2002; and Fernández-Arias and Hausmann 2000). One reason is that measured FDI does not reflect the "tied down" aspects of investment alone. Instead, it could represent incoming and outgoing flows that circumvent a country's capital controls and are merely substituting more volatile flows. Or they may be flows that pass through a particular country to reduce corporate tax liabilities or are used to obtain other funds holding physical assets as collateral. These aspects make FDI closer to portfolio debt flows that can fluctuate in the short term (Blanchard and Acalin 2016). Hence, countries have to be cautious about expanding their share of these flows without a deeper understanding of their interaction with other flows and the effects on stability (Lehmann, Sayek, and Kang 2004; Wu 2009; and Brukoff and Rother 2007). 
On the contrary, portfolio and banking flows are thought of as relatively destabilizing, but some country-specific cases find that these foreign investments have had a positive effect on stability when supported by appropriate macroeconomic policies (Pruski and Szpunar 2008).

The presence of mixed evidence in the literature, often with differing country experiences, suggests that stability effects of a particular component of capital flow in one country may not be the same for another. Our study contributes to the literature in the following dimensions. First, we begin with the premise that the relationship between flows and financial stability need not be the same across emerging market economies (EMEs). So, we explore whether there are significant effects of different flows on financial stability in different countries. Given the inconclusive evidence in the literature, we refrain from drawing hypotheses about the sign of the relation in each country and allow the data to highlight any significant positive and negative effects. The seemingly unrelated regression (SUR) method helps to facilitate the approach. For each country, the SUR allows flexibility in the cross-country estimated relationship, while permitting cross-equation restrictions to be imposed, as different flows and their effects on financial variables may be related within a country but not across countries. This methodology necessarily departs from previous studies that pool the effects of flows on stability for a panel of countries. Using this approach, we find that there are significant linkages between capital flows and financial stability proxies, but the effects are not homogeneous in magnitude nor sign across our sample economies.

Second, we analyze gross capital flows as opposed to net flows that have been used in past studies to assess effects on stability. Recent research has stressed the importance of focusing on gross capital flows, as sizable, positively correlated movements in both inward and outward flows may be masked by a net figure (Broner et al. 2013, and Pagliari and Hannan 2017). Our results show that, indeed, different types and directions of flows have different implications for domestic financial stability. We find that, across the sample economies, there is more evidence that FDI outflows tend to increase the volatility of financial indicators, while other investment outflows do not. The effects of FDI inflows, portfolio inflows and outflows, and other investment inflows are less clear.

Third, we address why the relationship between flows and stability varies across economies. Our results indicate that aggregate macroeconomic and financial characteristics of an economy may explain these heterogeneous effects. While assessing the variation in the magnitude of the relationship, for instance, in economies with a relatively higher aggregate-credit-to-deposit ratio (which indicates low liquidity), all flows, except portfolio inflows, tend to aggravate the volatility of financial indicators. Some macroeconomic variables such as income level, openness to trade, inflation rates, and exchange rate regimes determine a pattern in the signs of the estimates.

The rest of the paper is organized as follows. Section II discusses our selection of financial indicators and describes the capital flows data. It also outlines the empirical methodology used in the estimation. Section III provides our empirical findings, and section IV explores possible reasons for the results. Section $V$ discusses their implications and offers concluding remarks.

\section{DATA AND EMPIRICAL METHODOLOGY}

We describe the indicators used, data sources, and the estimation technique applied in the empirical investigation of the relationship between capital flows and financial stability. For the time period 19892011, three categories of quarterly panel data enter the analysis: a set of financial indicators that will be used to measure stability, a set of gross capital flows, and a set of macroeconomic control variables. The 
16 countries included in the analysis are Argentina, Brazil, Colombia, Czech Republic, Greece, Hungary, India, Indonesia, the Republic of Korea, Malaysia, Mexico, the Philippines, Poland, South Africa, Thailand, and Turkey. These countries were selected based on their data availability for flows and financial indicators.

\section{A. Data}

We select five key financial indicators to proxy financial stability for their relevance and availability for our sample economies from the World Bank's Global Financial Development Database (GFDD):

(i) Deposits: Financial system deposits to gross domestic product (GDP) (\%),

(ii) DomCredit: Domestic credit to private sector (\% of GDP),

(iii) NetlntMargin: Bank net interest margin (NIM) (\%),

(iv) NonperfLoan: Bank nonperforming loans to gross loans (\%), and

(v) LiqAssets: Liquid assets to deposits and short-term funding (\%).

These aggregate indicators are commonly used to represent features such as size, efficiency, accessibility, and quality of an economy's financial system.

The deposits-to-GDP ratio is traditionally used as a measure of size of the financial system relative to the economy and gives a sense of the extent of financial intermediation, especially through banks. The ratio also serves as an indicator of the availability of access to financial savings in countries where the financial structure is dominated by the banking system (IMF 2005).

The ratio of domestic credit to the private sector to GDP is another measure of depth of the financial sector, from the asset side as it measures loans made to the private sector by financial institutions. It is also considered as one of the proxies for the level of financial development of an economy.

In financial institutions, the NIM is the difference between interest income and interest expense, expressed as a ratio to the amount of their interest-earning assets. A wide margin typically reflects frictions in intermediation; so that a low value of NIM is considered a proxy for higher efficiency.

A nonperforming loan (NPL) is one that is in or close to a default. Measured relative to total gross loans, this ratio shows the quality of banking sector assets and may indicate weak capitalization of the banking sector.

The last ratio is the percentage of customer deposits and short-term funding that could be met if suddenly withdrawn. A higher ratio indicates more liquidity and lower vulnerability to a bank run.

For the purpose of proxying financial stability, we simply measure financial volatility as the standard deviation of the selected indicators, based on the idea that a financial system can be characterized as stable in the absence of excess volatility.

To describe the capital flows, six measures of commonly used gross capital flows concept available from the International Monetary Fund database are employed

(i) FDIAbroad: Outward FDI made by country $i$,

(ii) FDIReportCty: Inward FDI received by country $i$, 
(iii) PortlnvA: Flows of portfolio investments by country $i$

(iv) PortlnvL: Flows of portfolio liabilities of country $i$

(v) OtherInvA: Flows of other investments by country $i$, and

(vi) OtherlnvL: Flows of other liabilities of country $i$.

Other investment assets and other liabilities include trade credit and advances, loans, currency and deposits, and insurance and pensions etc. The financial account for country $i$ is defined by the net of these six measures plus the change in official reserve assets, which are not considered in this analysis, as they will reflect policy measures. In the empirical analysis, these six measures are expressed as percentages of nominal GDP.

To control for country specific macroeconomic factors, the following macroeconomic variables are used in once-lagged form. ${ }^{1}$

(i) Real GDP (deviations from stochastic trend via Christiano-Fitzgerald filter),

(ii) Exchange rate versus US dollars, end of period,

(iii) Net exports as a ratio to nominal GDP, and

(iv) Inflation rate, percent per annum.

The resulting panel is unbalanced quarterly data from the first quarter of 1989 through the fourth quarter of 2011.

\section{B. Estimation Strategy}

We seek to identify the effects of the components of gross capital flows on a number of financial stability proxies in unbalanced panels of cross-country data. In this context, we allow each country to have its own coefficient vector and error variance, as there is no reason to believe that the magnitude of these effects, or even their signs, may be equal across countries. To this end, we make use of Zellner's (1962) SUR estimator, specifying a separate equation for each country for each of the financial stability proxy variables. While the regression equations may be correlated for a country, they may be uncorrelated between countries. Unlike more restrictive approaches such as fixed-effects models, the use of SUR allows complete flexibility of the estimated relationships, i.e., country-specific coefficients, while allowing for cross-equation restrictions to be tested and, if warranted, imposed on the equation system.

For each individual observation of $i=1, \ldots, N$ (country) in the model, there are $M$ dependent variables (financial indicators), each with its own regression equation

$$
y_{i j}=x_{i j}^{\prime} \beta_{j}+u_{i j}
$$

for $j=1, \ldots, M$. The error terms are assumed to have zero mean.

The SUR model allows nonzero covariance between the error terms $u_{i j}$ for a given $i$ across equations $j$ and $k$, i.e.,

$$
\operatorname{Cov}\left(u_{i j}, u_{i k}\right)=\sigma_{i j}
$$

1 The data sources are CEIC Data and Haver Analytics. 
while assuming zero covariance between i's

$$
\operatorname{Cov}\left(u_{i j}, u_{i^{\prime} k}\right)=0
$$

if $i \neq i^{\prime}$.

Estimation of a system of country-level equations provides for a gain in the efficiency of the estimates by taking the contemporaneous correlation of cross-country shocks into account. As the literature remains inconclusive about the nature of relationship between financial stability and capital flows, we refrain from attaching a prior regarding the signs of our estimated coefficients, $\beta$, as they can differ by country and type of flow.

In the empirical analysis, we specify two systems of SURs for each of the five measures of financial stability: a total of 10 sets of estimates. Each system contains country-specific dependent variables for one proxy measure (e.g., the volatility of financial deposits ratio for country i), with country-specific regressors representing the six components of gross capital flows and the macroeconomic control variables. The first system expresses the level of the financial stability proxy in terms of the levels of gross capital flows. The second system models the volatility of the financial stability proxy as related to the levels of gross capital flow. Volatilities for the financial stability proxies are computed from four-quarter rolling standard deviations of the level measures. As the financial indicators are reported annually in GFDD the proportional Denton interpolation procedure is used to create quarterly series (Baum 2001).

\section{EMPIRICAL FINDINGS}

As each of the 10 estimated SUR systems include up to 96 slope coefficients for the gross capital flow components, we summarize our preliminary findings below in terms of the number of significant positive and negative relationships detected in each of the systems. There are up to 16 country-specific coefficients for each combination of gross capital flow component and financial stability proxy. Given the unbalanced nature of the panel, some countries' data do not appear in all the estimated systems.

\section{A. Summary of Findings for the Levels of Financial Indicators versus Levels of Capital Flows}

For the levels of the financial indicators, Table 1 reports the percentage of coefficients (up to 16) that are significantly different from zero, at the 10\% level of significance. Table 2 reports the number of significant positive relationships detected, while Table 3 reports the corresponding number of significant negative relationships. Table 4 reports the number of net significant relationships, that is, the number of significant positive relationships minus the number of significant negative relationships. As we can see from Table 1, many of the levels of financial indicators are seen to be meaningfully related to gross capital flows in half or more of the countries studied.

From the results, we see that larger outward FDI flows have a mixed effect on financial indicators, with a large negative impact on NIM and liquid assets. Larger inward FDI flows also have a mixed effect overall, with a relatively stronger negative effect on deposits. It appears that most of the financial indicators are indeed related to gross FDI flows.

Turning to portfolio investment, increases in portfolio investment assets and liabilities both have clear effects on financial indicators, but mixed across the country sample for assets and relatively more negative for liabilities. Other investment assets have a predominantly positive effect on most financial 
indicators, whereas the effects are more negative for other investment liabilities, particularly for NPLs. We may conclude that both these categories of gross capital flows have meaningful effects on most countries' financial indicators.

Table 1: Levels of Financial Stability Proxies versus Levels of Capital Flows:

Percentage of Significant Coefficients

(up to 16 countries)

\begin{tabular}{|c|c|c|c|c|c|c|}
\hline & FDIAbroad & FDIReportCty & PortlnvA & PortlnvL & OtherlnvA & OtherlnvL \\
\hline Deposits & 13 & 50 & 44 & 44 & 6 & 25 \\
\hline DomCredit & 29 & 43 & 29 & 43 & 36 & 50 \\
\hline NetlntMargin & 43 & 36 & 64 & 36 & 36 & 50 \\
\hline NonperfLoan & 31 & 56 & 25 & 56 & 38 & 38 \\
\hline LiqAssets & 57 & 36 & 57 & 50 & 14 & 43 \\
\hline
\end{tabular}

Source: Authors' computation.

Table 2: Levels of Financial Stability Proxies versus Levels of Capital Flows: Significant Positive Coefficients (up to 16 countries)

\begin{tabular}{lcccccc}
\hline & FDIAbroad & FDIReportCty & PortlnvA & PortlnvL & OtherlnvA & OtherlnvL \\
\hline Deposits & 1 & 2 & 4 & 3 & 1 & 1 \\
DomCredit & 1 & 3 & 1 & 3 & 4 & 4 \\
NetIntMargin & 1 & 2 & 4 & 2 & 4 & 2 \\
NonperfLoan & 4 & 5 & 2 & 3 & 3 & 0 \\
LiqAssets & 2 & 4 & 5 & 4 & 1 & 3 \\
\hline
\end{tabular}

Source: Authors' computation.

Table 3: Levels of Financial Stability Proxies versus Levels of Capital Flows: Significant Negative Coefficients (up to 16 countries)

\begin{tabular}{lcccccc}
\hline & FDIAbroad & FDIReportCty & PortlnvA & PortlnvL & OtherlnvA & OtherInvL \\
\hline Deposits & 1 & 6 & 3 & 4 & 0 & 3 \\
DomCredit & 3 & 3 & 3 & 3 & 1 & 3 \\
NetIntMargin & 5 & 3 & 5 & 3 & 1 & 5 \\
NonperfLoan & 1 & 4 & 2 & 6 & 3 & 6 \\
LiqAssets & 6 & 1 & 3 & 3 & 1 & 3 \\
\hline
\end{tabular}

Source: Authors' computation.

Table 4: Levels of Financial Stability Proxies versus Levels of Capital Flows: Net Significant Coefficients

(up to 16 countries)

\begin{tabular}{lcccccc}
\hline & FDIAbroad & FDIReportCty & PortlnvA & PortlnvL & OtherlnvA & OtherlnvL \\
\hline Deposits & 0 & -4 & 1 & -1 & 1 & -2 \\
DomCredit & -2 & 0 & -2 & 0 & 3 & 1 \\
NetIntMargin & -4 & -1 & -1 & -1 & 3 & -3 \\
NonperfLoan & 3 & 1 & 0 & -3 & 0 & -6 \\
LiqAssets & -4 & 3 & 2 & 1 & 0 & 0 \\
\hline
\end{tabular}

Source: Authors' computation. 


\section{B. A Robustness Check with Annual Data}

When interpolation procedures are used, there is naturally a concern that they may have qualitative effects on the empirical findings. To investigate this issue, the first set of SUR models (on the levels of the financial indicators) have been reestimated on the original annual GFDD data, with the gross portfolio flows data aggregated to annual frequency. This necessarily reduces the variability of the gross flows data and their explanatory power, and reduces the sample size in the SUR models by a factor of four. On the other hand, employing the response variable in its original form reduces the variation to be explained.

Tables 5-8 may be compared with their counterparts from the quarterly measures, Tables 1-4. Table 5 illustrates that each of the gross capital flow variables have more prevalent effects on the levels of financial stability proxies in the annual data. In Tables 6-7, we see that the effects are again mixed for the sample economies for most of the gross capital flow measures. Table 8 reinforces this conclusion.

Although these results suggest that there is stronger empirical support for our hypotheses in the annual data, they should be treated with caution due to the very limited sample size of some of these regressions. Further, although it is straightforward to aggregate the gross capital flows to annual measures, it is not sensible to compute volatility measures for the financial stability indicators from the original annual data, as in several cases it would exhaust the available data to compute four-quarter moving average standard deviations. Therefore, analysis of the effects of gross capital flows on the volatility of the financial indicators can only be performed on the quarterly interpolated data. The robustness checks presented here clearly indicate that we are not manufacturing findings by applying the interpolation procedure. If anything, we are raising the bar for detecting significant relationships. Thus, proceeding with the quarterly interpolated data seems to be a sensible strategy.

\section{Table 5: Levels of Capital Flows: Percentage of Significant Coefficients (up to 16 countries)}

\begin{tabular}{lcccccc}
\hline & FDIAbroad & FDIReportCty & PortlnvA & PortlnvL & OtherlnvA & OtherlnvL \\
\hline Deposits & 50 & 40 & 60 & 60 & 60 & 50 \\
DomCredit & 60 & 40 & 50 & 50 & 50 & 50 \\
NetIntMargin & 40 & 60 & 40 & 20 & 60 & 50 \\
NonperfLoan & 56 & 33 & 44 & 44 & 44 & 67 \\
LiqAssets & 30 & 70 & 50 & 40 & 50 & 50 \\
\hline
\end{tabular}

Source: Authors' computation.

Table 6: Levels of Capital Flows: Significant Positive Coefficients (up to 16 countries)

\begin{tabular}{lcccccc}
\hline & FDIAbroad & FDIReportCty & PortlnvA & PortlnvL & OtherlnvA & OtherlnvL \\
\hline Deposits & 1 & 2 & 2 & 1 & 4 & 4 \\
DomCredit & 3 & 1 & 3 & 3 & 3 & 4 \\
NetIntMargin & 1 & 3 & 2 & 2 & 3 & 2 \\
NonperfLoan & 3 & 1 & 1 & 1 & 1 & 0 \\
LiqAssets & 0 & 4 & 3 & 2 & 3 & 1 \\
\hline
\end{tabular}

Source: Authors' computation. 
Table 7: Levels of Capital Flows: Significant Negative Coefficients (up to 16 countries)

\begin{tabular}{lcccccc}
\hline & FDIAbroad & FDIReportCty & PortlnvA & PortInvL & OtherInvA & OtherInvL \\
\hline Deposits & 4 & 2 & 4 & 5 & 2 & 1 \\
DomCredit & 3 & 3 & 2 & 2 & 2 & 1 \\
NetIntMargin & 3 & 3 & 2 & 0 & 3 & 3 \\
NonperfLoan & 2 & 2 & 3 & 3 & 3 & 6 \\
LiqAssets & 3 & 3 & 2 & 2 & 2 & 4 \\
\hline
\end{tabular}

Source: Authors' computation.

Table 8: Levels of Capital Flows: Net Significant Coefficients (up to 16 countries)

\begin{tabular}{lcccccc}
\hline & FDIAbroad & FDIReportCty & PortInvA & PortInvL & OtherInvA & OtherInvL \\
\hline Deposits & -3 & 0 & -2 & -4 & 2 & 3 \\
DomCredit & 0 & -2 & 1 & 1 & 1 & 3 \\
NetIntMargin & -2 & 0 & 0 & 2 & 0 & -1 \\
NonperfLoan & 1 & -1 & -2 & -2 & -2 & -6 \\
LiqAssets & -3 & 1 & 1 & 0 & 1 & -3 \\
\hline
\end{tabular}

Source: Authors' computation.

\section{Summary of Findings for the Volatility of Financial Indicators versus the Level of Capital Flows}

The impact of gross capital flows on financial sector conditions may manifest itself in terms of the levels of these proxies, as we have discussed, but it may also have important effects on their volatility. Indeed, there may be more concern about the variability of these indicators as they are acting as proxies for financial stability. If there are wide variations in these ratios-for instance, in the NIM earned by the banking sector - that may significantly reduce the stability of the financial sector, and call into question the adequacy of financial intermediaries' capitalization. Thus, we repeat the estimation for the volatility measures of the financial indicators rather than their levels.

Tables 9-12 report the results as described earlier. Note that a positive coefficient implies that the capital flow increases the volatility of a financial indicator, and vice versa for a negative coefficient.

Table 9 reveals that gross capital flows have significant effects on the volatility of the financial indicators in most cases, with countries reporting significant relationships for many proxies. These effects may take either sign, as Tables 10-12 reveal. For instance, larger outward FDI flows have a net positive effect on all the proxies, while the effects of inward FDI flows are mixed. Table 10 reveals that outward FDI flows have strong positive effects on volatility of domestic credit, liquid assets, and NPL ratios for a number of countries, and inward FDI flow on volatility of deposits and domestic credit.

Portfolio investment flows have strong effects on a number of proxies, but their signs are somewhat mixed. Portfolio investment outflows have a negative effect on domestic credit, and inflows have negative effects on domestic credit, NIM, and NPLs. Both flows have positive effects on liquid assets, while other investment asset and liability flows have generally negative effects on the volatility of financial proxies, except for the latter on liquid assets. 
Table 9: Volatility of Financial Stability Proxies versus Levels of Capital Flows:

Percentage of Significant Coefficients

(up to 16 countries)

\begin{tabular}{lcccccc}
\hline & FDIAbroad & FDIReportCty & PortlnvA & PortlnvL & OtherlnvA & OtherlnvL \\
\hline Deposits & 44 & 69 & 69 & 50 & 50 & 44 \\
DomCredit & 50 & 75 & 44 & 44 & 38 & 38 \\
NetIntMargin & 27 & 53 & 47 & 47 & 53 & 13 \\
NonperfLoan & 40 & 33 & 40 & 60 & 20 & 27 \\
LiqAssets & 53 & 20 & 47 & 60 & 27 & 47 \\
\hline
\end{tabular}

Source: Authors' computation.

Table 10: Volatility of Financial Stability Proxies versus Levels of Capital Flows: Significant Positive Coefficients (up to 16 countries)

\begin{tabular}{lcccccc}
\hline & FDIAbroad & FDIReportCty & PortlnvA & PortlnvL & OtherlnvA & OtherlnvL \\
\hline Deposits & 4 & 9 & 6 & 4 & 4 & 2 \\
DomCredit & 5 & 5 & 2 & 3 & 1 & 1 \\
NetIntMargin & 3 & 2 & 4 & 3 & 0 & 1 \\
NonperfLoan & 5 & 2 & 4 & 3 & 0 & 1 \\
LiqAssets & 5 & 2 & 5 & 6 & 1 & 5 \\
\hline
\end{tabular}

Source: Authors' computation.

Table 11: Volatility of Financial Stability Proxies versus Levels of Capital Flows: Significant Negative Coefficients (up to 16 countries)

\begin{tabular}{lcccccc}
\hline & FDIAbroad & FDIReportCty & PortlnvA & PortlnvL & OtherlnvA & OtherlnvL \\
\hline Deposits & 3 & 2 & 5 & 4 & 4 & 5 \\
DomCredit & 3 & 7 & 5 & 4 & 5 & 5 \\
NetIntMargin & 1 & 6 & 3 & 4 & 8 & 1 \\
NonperfLoan & 1 & 3 & 2 & 6 & 3 & 3 \\
LiqAssets & 3 & 1 & 2 & 3 & 3 & 2 \\
\hline
\end{tabular}

Source: Authors' computation.

Table 12: Volatility of Financial Stability Proxies versus Levels of Capital Flows: Net Significant Coefficients (up to 16 countries)

\begin{tabular}{lcccccc}
\hline & FDIAbroad & FDIReportCty & PortInvA & PortInvL & OtherInvA & OtherlnvL \\
\hline Deposits & 1 & 7 & 1 & 0 & 0 & -3 \\
DomCredit & 2 & -2 & -3 & -1 & -4 & -4 \\
NetIntMargin & 2 & -4 & 1 & -1 & -8 & 0 \\
NonperfLoan & 4 & -1 & 2 & -3 & -3 & -2 \\
LiqAssets & 2 & 1 & 3 & 3 & -2 & 3 \\
\hline
\end{tabular}

Source: Authors' computation. 
In summary, it appears that capital flows have a significant effect on volatility of financial indicators, but the effects are heterogeneous across countries and across flows. When we look at the overall picture for the sample EMEs, there is strong evidence that higher FDI outflows have a larger positive effect on volatility and higher other investment outflows have a negative effect on volatility of most of the financial indicators. With FDI inflows, portfolio inflows and outflows, and other investment inflows, the results are slightly mixed across financial proxies, with significant effects.

\section{UNTANGLING THE MIXED EFFECTS}

Despite the significant linkages between flows and the volatility of financial proxies that capture the state of financial stability in the economies under study, our empirical results seem to be in line with previous findings in the literature on the inconclusive relation. The magnitude and signs of the statistically significant coefficients reported in the previous subsection vary across countries. We confront those estimated coefficients with several financial aggregates and macroeconomic variables to look for meaningful patterns that may shed light on possible reasons behind the cross-country differences. We only explore simple correlations between country-specific characteristics and the estimates from the empirical analysis.

The financial aggregates considered here are (i) the relative size of the banking sector in the economy (represented by the deposit money banks' assets to GDP), (ii) the credit-to-deposit ratio, and (iii) the liquid-assets-to-deposit ratio. The macroeconomic variables considered are (i) real GDP per capita, (ii) the degree of trade openness (the sum of exports and imports as a ratio to GDP), (iii) rate of inflation, and (iv) the exchange rate regime proxied by the degree of exchange rate volatility. For the first three indicators, we take the median across years as the range is quite large for some economies. For exchange rate volatility, we measure the standard deviation of the series.

\section{A. Financial Aggregates}

To look for plausible patterns in the magnitude of the coefficients, we juxtapose the significant estimates against financial aggregates and see if an obvious trend emerges. The results are summarized in Table 13.

The relative size of the banking sector appears to be related with the effect of capital flows on financial stability. A larger ratio of bank assets to GDP tends to be associated with higher effects of FDI and other investment inflows on the volatility of deposits, domestic credit, NIM, and NPLs. Hence, the effects on financial volatility of FDI and other investment inflows are stronger in countries with a larger banking sector. Outflows of FDI and other investments, on the other hand, tend to have a weaker effect on financial volatility as the size of the banking sector increases across countries. The effects of portfolio flows on financial volatility are the opposite of those of FDI and other investments, where outflows tend to be associated with higher volatility effects in countries with a larger banking sector, and vice versa.

When compared with the credit-to-deposit ratio, it seems that almost all types of capital flows tend to aggravate volatility of financial proxies as the ratio increases. The only exception is portfolio inflows, which are associated with lower volatility in countries with a larger credit-to-deposit ratio. ${ }^{2}$

2 The ratio indicates what percentage of deposits is loaned out by the financial intermediary. A higher ratio indicates lower liquidity. 
The effect of portfolio inflows on financial stability reverses when evaluated at different levels of the ratio of liquid assets to deposits and short-term funding. Larger portfolio inflows tend to be associated with greater financial volatility in countries with larger liquid assets. This also holds for outflows of FDI and other investments. Other investment inflows and FDI inflows, on the contrary, tend to have a smaller effect on volatility in countries with larger liquid assets.

These patterns suggest that the relation between gross capital flows and financial stability is complex and far from straightforward. They also shed some light on factors that underlie the heterogeneity in the empirical relation between capital flows and financial stability. We further examine possible patterns in the signs of the estimated coefficients against macroeconomic variables.

\section{B. Macroeconomic Variables}

To further explore reasons why the same type of flow does not necessarily have the same impact on financial stability in all economies, we also assess whether characteristics particular to the economy can explain the heterogeneity. We compare the magnitude of the coefficient from the estimated relation between capital flows and volatility of the financial proxy against an economy's macroeconomic indicators and report the direction of correlation, if any, in Table $14 .^{3}$

Differences in the impact of portfolio flows on the volatility of different financial stability measures are the ones that appear most consistently when dissected against macroeconomic indicators. Portfolio inflows tend to amplify the volatility of financial indicators more in countries with higher exchange rate variability and higher inflation rates. ${ }^{4}$ Portfolio outflows dampen financial sector volatility, on the other hand, in countries with higher income as measured by the real GDP per capita. In short, portfolio inflows are found to be more harmful for financial sector stability in emerging countries with more flexible exchange rate regime and/or in countries with higher inflation records, while portfolio outflows are less harmful in higher-income countries.

Table 13: Relation between Financial Aggregates and Estimated Coefficients between Flows and All Financial Indicators

\begin{tabular}{lll}
\hline & \multicolumn{1}{c}{ Positive Correlation } & \multicolumn{1}{c}{ Negative Correlation } \\
\hline $\begin{array}{l}\text { Bank assets/gross } \\
\text { domestic product }\end{array}$ & FDI outflow & $\begin{array}{l}\text { FDI inflow } \\
\text { Portfolio inflow } \\
\end{array}$ \\
& Other investment inflow \\
& Other investment outflow \\
\hline Credit/deposits & Other investment inflow & FDI inflow \\
& Other investment outflow & FDI outflow \\
& Portfolio outflow & Portfolio inflow \\
\hline Liquid assets/deposits & FDI inflow & FDI outflow \\
& Portfolio inflow & \\
& Portfolio outflow & \\
& Other investment inflow & \\
& Other investment outflow & \\
& & \\
\end{tabular}

$\mathrm{FDI}=$ foreign direct investment.

Source: Based on authors' computations.

3 We remove any outliers that tend to bias the correlation in a particular direction and also do not report if the correlation is close to zero.

4 We use the standard deviation of the exchange rate (period average) of an economy with lower variability pertaining to a more fixed-rate regime and higher variability to a more flexible one. 
The effects of other types of flows are not as clear. When seen through differences in exchange rate stability, we see some patterns emerge with regard to other flows and volatility of different financial proxies. In countries with a relatively fixed-rate regime, the impact of FDI inflows on financial volatility is higher than in countries with a relatively floating-rate regime. The result is reversed for FDI outflows for most of the financial proxies, i.e., outflows tend to worsen financial stability in a more flexible exchange rate regime. Other investment flows tend to behave similarly as FDI flows with regard to exchange rate regimes, but the pattern is not as consistent across indicators.

As we are comparing across countries, we use median GDP per capita to characterize their relative performance. The estimated coefficient between other investment outflows and volatility of financial proxies reflects a positive relation to GDP per capita, suggesting that outflows worsen financial stability in higher-income countries. With regard to inflation, in countries with lower median inflation, FDI outflows are associated with higher volatility of financial variables than in countries with higher inflation.

Trade openness is another macroeconomic indicator that we use to distinguish between countries. Here, even portfolio flows do not show a consistent pattern. Both portfolio inflows and outflows have a higher impact on financial volatility in countries with relatively low openness to trade than in those with more openness. An exception appears for domestic credit, where portfolio inflows seem to increase volatility in more open economies. FDI inflows and outflows show the opposite pattern from portfolio flows, where they tend to increase volatility of financial proxies in more open economies compared with less open ones, except in the case of domestic deposits. 
Table 14: Relation between Macroeconomic Aggregates and Estimated Coefficients between Flows and Financial Indicators

\begin{tabular}{|c|c|c|c|c|c|c|c|c|}
\hline \multirow{2}{*}{$\begin{array}{l}\text { Financial } \\
\text { Volatility }\end{array}$} & \multicolumn{2}{|c|}{$\begin{array}{c}\text { Real Gross Domestic Product Per } \\
\text { Capita }\end{array}$} & \multicolumn{2}{|c|}{ Trade Openness } & \multicolumn{2}{|c|}{ Inflation } & \multicolumn{2}{|c|}{ Exchange Rate } \\
\hline & Positive & Negative & Positive & Negative & Positive & Negative & Positive & Negative \\
\hline Deposits & $\begin{array}{l}\text { FDI inflow } \\
\text { Other inv outflow } \\
\text { Other inv inflow }\end{array}$ & Portfolio outflow & Other inv inflow & $\begin{array}{l}\text { FDI outflow } \\
\text { FDI inflow } \\
\text { Portfolio outflow }\end{array}$ & $\begin{array}{l}\text { FDI outflow } \\
\text { Portfolio inflow }\end{array}$ & $\begin{array}{l}\text { Other inv outflow } \\
\text { FDI inflow } \\
\text { Other inv inflow }\end{array}$ & $\begin{array}{l}\text { FDI outflow } \\
\text { Portfolio inflow }\end{array}$ & $\begin{array}{l}\text { Other inv outflow } \\
\text { Other inv inflow } \\
\text { Portfolio outflow }\end{array}$ \\
\hline $\begin{array}{l}\text { Domestic } \\
\text { credit }\end{array}$ & $\begin{array}{l}\text { FDI outflow } \\
\text { Other inv outflow } \\
\text { Other inv inflow }\end{array}$ & $\begin{array}{l}\text { Portfolio outflow } \\
\text { Portfolio inflow }\end{array}$ & $\begin{array}{l}\text { FDI outflow } \\
\text { FDI inflow } \\
\text { Portfolio inflow }\end{array}$ & Other inv inflow & $\begin{array}{l}\text { Other inv inflow } \\
\text { FDI inflow } \\
\text { Other inv outflow } \\
\text { Portfolio inflow }\end{array}$ & FDI outflow & $\begin{array}{l}\text { FDI outflow } \\
\text { Other inv outflow } \\
\text { Portfolio inflow }\end{array}$ & $\begin{array}{l}\text { FDI inflow } \\
\text { Other inv inflow } \\
\text { Portfolio outflow }\end{array}$ \\
\hline $\begin{array}{l}\text { Net interest } \\
\text { margin }\end{array}$ & Other inv outflow & $\begin{array}{l}\text { FDI inflow } \\
\text { Portfolio outflow } \\
\text { Portfolio inflow }\end{array}$ & $\begin{array}{l}\text { FDI inflow } \\
\text { Other inv outflow }\end{array}$ & $\begin{array}{l}\text { Portfolio outflow } \\
\text { Portfolio inflow }\end{array}$ & & Other inv outflow & $\begin{array}{l}\text { Other inv outflow } \\
\text { Portfolio outflow } \\
\text { Portfolio inflow }\end{array}$ & $\begin{array}{l}\text { FDI outflow } \\
\text { FDI inflow }\end{array}$ \\
\hline $\begin{array}{l}\text { Nonperforming } \\
\text { loan }\end{array}$ & $\begin{array}{l}\text { FDI outflow } \\
\text { FDI inflow }\end{array}$ & Portfolio outflow & $\begin{array}{l}\text { FDI outflow } \\
\text { FDI inflow } \\
\text { Other inv inflow }\end{array}$ & $\begin{array}{l}\text { Portfolio outflow } \\
\text { Portfolio inflow }\end{array}$ & $\begin{array}{l}\text { Portfolio outflow } \\
\text { Portfolio inflow }\end{array}$ & $\begin{array}{l}\text { FDI outflow } \\
\text { Other inv inflow }\end{array}$ & $\begin{array}{l}\text { FDI outflow } \\
\text { Portfolio inflow }\end{array}$ & $\begin{array}{l}\text { FDI inflow } \\
\text { Other inv outflow } \\
\text { Other inv inflow } \\
\text { Portfolio outflow }\end{array}$ \\
\hline Liquid assets & Portfolio inflow & Portfolio outflow & FDI outflow & $\begin{array}{l}\text { Other inv inflow } \\
\text { Portfolio outflow } \\
\text { Portfolio inflow }\end{array}$ & $\begin{array}{l}\text { Other inv inflow } \\
\text { Portfolio outflow } \\
\text { Portfolio inflow }\end{array}$ & FDI outflow & $\begin{array}{l}\text { FDI outflow } \\
\text { Portfolio outflow } \\
\text { Portfolio inflow }\end{array}$ & $\begin{array}{l}\text { FDI inflow } \\
\text { Other inv outflow } \\
\text { Other inv inflow }\end{array}$ \\
\hline
\end{tabular}

FDI = foreign direct investment, inv = investment.

Source: Based on authors' computations. 


\section{CONCLUDING REMARKS}

In conclusion, this investigation of the relationship between quarterly gross capital flows and proxies for financial stability in a cross-country setting reveals that there are significant effects of gross flows' levels on both the level and volatility of the financial indicators after controlling for a number of macroeconomic factors. Robustness checks on the level series conducted at the annual frequency indicate that the results are not sensitive to the interpolation procedure applied to the financial stability proxies.

The results of this study are consistent with the seemingly divergent evidence in the literature on the relationship between capital flows and financial stability. In much of this research, EMEs are treated as a group due to their similar experiences with regard to movement of flows or are sometimes pooled into a larger panel with advanced economies to take advantage of cross-country variation in their experience. As this approach imposes restrictions on the relationship, we use the SUR approach to enable greater flexibility. Our investigation reveals that the effects of capital flows on financial stability vary quite substantially across countries and, interestingly, across types of flows. The variation is found not only in terms of magnitude, but also in the estimated signs of the coefficients: the same type of flows have differing effects in different countries.

We provide possible explanations for these variations by showing that the differences in coefficients can be partly explained by the differences in financial and macroeconomic characteristics of the economy. The meaningful patterns discussed in our study shed some light on why the effect of capital flows on financial stability may differ across emerging economies, and offer a possible agenda for

future research to more fully understand the nature of the relation between particular capital flows and financial stability. 


\section{REFERENCES*}

Ahmed, Abdulahi D., and Sandy Suardi. 2009. "Macroeconomic Volatility, Trade and Financial Liberalization in Africa.” World Development 37 (10): 1623-36.

Albuquerque, Rui. 2003. "The Composition of International Capital Flows: Risk Sharing through Foreign Direct Investment.” Journal of International Economics 61 (2): 353-83.

Baum, Christopher F. 2001. “Denton: Stata Module to Interpolate a Quarterly Flow Series from Annual Totals via Proportional Denton Method.” https://ideas.repec.org/c/boc/bocode/s422501.html

Bird, Graham, and Ramkishen S. Rajan. 2002. "Does FDI Guarantee the Stability of International Capital Flows? Evidence from Malaysia.” Development Policy Review 20 (2): 191-202.

Blanchard, Olivier, and Julien Acalin. 2016. "What Does Measured FDI Actually Measure?” Technical Report PB 16-17. Washington, DC: Peterson Institute for International Economics.

Broner, Fernando, Tatiana Didier, Aitor Erce, and Sergio L. Schmukler. 2013. "Gross Capital Flows: Dynamics and Crises." Journal of Monetary Economics 60 (1): 113-33.

Brukoff, Patricia, and Bjorn Rother. 2007. “FDI May Not Be as Stable as Governments Think.” IMF Policy Development and Review Department, IMF Survey Magazine: IMF Research 29.

Claessens, Stijn, Michael P. Dooley, and Andrew Warner. 1995. “Portfolio Capital Flows: Hot or Cold?” The World Bank Economic Review 9 (1): 153-74.

Corsetti, Giancarlo, Paolo Pesenti, and Nouriel Roubini. 1999. "What Caused the Asian Currency and Financial Crisis?" Japan and the World Economy 11 (3): 305-73.

Daniel, Betty C., and John Baily Jones. 2007. "Financial Liberalization and Banking Crises in Emerging Economies.” Journal of International Economics 72 (1): 202-21.

Erturk, Korkut A. 2005. “Economic Volatility and Capital Account Liberalization in Emerging Countries.” International Review of Applied Economics 19 (4): 399-417.

Fernández-Arias, Eduardo, and Ricardo Hausmann. 2001. “Is FDI a Safer Form of Financing?” Emerging Markets Review 2 (1): 34-49.

Hegerty, Scott W. 2011. “Do International Capital Flows Smooth or Transmit Macroeconomic Volatility? Time-Series Evidence from Emerging Markets.” Economics Bulletin 31 (2): 1659-72.

International Monetary Fund (IMF). 2005. Financial Sector Assessment: A Handbook. Washington, DC.

Kaminsky, Graciela L. 2005. "International Capital Flows, Financial Stability and Growth.” United Nations Department of Economics and Social Affairs (UN DESA) Working Paper 10.

*ADB recognizes “China” as the People's Republic of China. 
Kaminsky, Graciela L., and Carmen M. Reinhart. 1999. "The Twin Crises: The Causes of Banking and Balance-of-Payments Problems.” American Economic Review 89 (3): 473-500.

Kaminsky, Graciela L., and Sergio L. Schmukler. 2008. "Short-Run Pain, Long-Run Gain: Financial Liberalization and Stock Market Cycles." Review of Finance 12 (2): 253-92.

Kim, E. Han, and Vijay Singal. 2000. "The Fear of Globalizing Capital Markets." Emerging Markets Review 1 (3): 183-98.

Kose, M. Ayhan, Eswar Prasad, Kenneth Rogoff, and Shang-Jin Wei. 2009. "Financial Globalization: A Reappraisal.” IMF Staff Papers, 8-62.

Kose, M. Ayhan, Eswar S. Prasad, and Marco E. Terrones. 2003. "Financial Integration and Macroeconomic Volatility." IMF Staff Working Papers WP/03/50.

Lehmann, Alexander, Selin Sayek, and Hyoung Goo Kang. 2004. "Multinational Affiliates and Local Financial Markets." IMF Working Paper WP/04/107.

Levchenko, Andrei A., and Paolo Mauro. 2007. "Do Some Forms of Financial Flows Help Protect Against Sudden Stops?” World Bank Economic Review 21 (3): 389-411.

Milesi-Ferretti, Gian-Maria, and Cédric Tille. 2011. "The Great Retrenchment: International Capital Flows during the Global Financial Crisis.” Economic Policy 26 (66): 287-342.

Pagliari, Maria Sole, and Swarnali Ahmed Hannan. 2017. "The Volatility of Capital Flows in Emerging Markets: Measures and Determinants." IMF Working Paper WP/17/41.

Pruski, Jerzy, and Piotr Szpunar. 2008. "Capital Flows and Their Implications for Monetary and Financial Stability: The Experience of Poland." In Financial Globalisation and Emerging Market Capital Flows, 403-84. BIS Papers No. 44.

Sula, Ozan, and Thomas. D. Willett. 2009. "The Reversibility of Different Types of Capital Flows to Emerging Markets.” Emerging Markets Review 10 (4): 296-310.

Wei, Shang-Jin. 2001. "Domestic Crony Capitalism and International Fickle Capital: Is There a Connection?” International Finance 4 (1): 15-45.

Wu, Zhongmin. 2009. Financial Sector Reform and the International Integration of China. Routledge.

Zellner, Arnold. 1962. "An Efficient Method of Estimating Seemingly Unrelated Regressions and Tests for Aggregation Bias.” Journal of the American Statistical Association 57 (298): 348-68. 


\section{Capital Flows and Financial Stability in Emerging Economies}

Evidence for the impact of international capital flows on the financial sector's stability is mixed.

This paper assesses the relationship between capital flows and financial stability in emerging economies. The findings suggest that, after controlling for several macroeconomic factors, there are significant effects of different gross capital flow measures on the financial stability proxies, but they are not homogeneous across economies and across flow types. The paper proposes several country-specific financial and macroeconomic characteristics to help explain these differences.

\section{About the Asian Development Bank}

ADB's vision is an Asia and Pacific region free of poverty. Its mission is to help its developing member countries reduce poverty and improve the quality of life of their people. Despite the region's many successes, it remains home to a large share of the world's poor. ADB is committed to reducing poverty through inclusive economic growth, environmentally sustainable growth, and regional integration.

Based in Manila, ADB is owned by 67 members, including 48 from the region. Its main instruments for helping its developing member countries are policy dialogue, loans, equity investments, guarantees, grants, and technical assistance. 